\title{
A interatividade como protagonista na Current TV: uma nova forma de fazer televisão ${ }^{1}$
}

Renata Barreto Malta²

\begin{abstract}
Resumo: Por meio deste trabalho, pretendemos mostrar como a comunicação unilateral vem se modificando através da inserção do público no processo de produção do comunicado. A internet aparece como grande pivô de transformação, garantindo ao usuário o poder de interagir. Seguindo essa tendência, os outros meios, como a televisão, buscam maior interação com o seu público, ainda que ela não seja um meio de comunicação interativo em sua essência. Neste artigo, analisamos, como objeto de pesquisa, a Current TV, uma televisão americana via satélite e a cabo, que também está presente na internet, e tem como proposta a inclusão da audiência no processo de produção do conteúdo transmitido por ela. Percebemos, assim, que a emissora ora citada inova quando foca na interação mútua, e não apenas na reativa.
\end{abstract}

Palavras-chave: comunicação, interatividade, televisão.

\begin{abstract}
The aim of this paper is to show how unilateral communication has changed with the insertion of the audience in the message-production process. The internet comes as an important pivot of transformation, acknowledging to the user the power of interaction. Following this trend, other media, such as the television, look for more interactivity with its audience, even though television cannot be considered an interactive media in its essence. In the present paper we analyze as research object the "Current TV", an American television channel broadcasted by satellite and cable, which also is available on the internet. It has as value the inclusion of the audience in the messageproduction process. Therefore, we realized that the channel here studied innovates while focusing on the mutual interaction, and not only on the reactive interaction.
\end{abstract}

Keywords: communication, interactivity, television. 


\section{O princípio da interatividade}

Ao classificar os meios de comunicação como quentes e frios, McLuhan (1964) já antevia a tendência de tais meios de permitir, em maior ou menor grau, a participação do público no processo comunicacional. Segundo sua classificação, os meios quentes permitiriam pouca ou nenhuma intervenção, enquanto que os meios frios estimulariam o desejo do público de participação, já que os mesmos estariam abertos à interação. A televisão seria, então, um meio frio, de baixa definição.

\footnotetext{
Três milhões de pontos por segundo formam a imagem-chuveiro que o telespectador recebe. Destes, ele capta algumas poucas dúzias, com as quais forma uma imagem. A imagem do filme apresenta muitos milhões mais de dados por segundo, e o espectador não tem de reduzi-los drasticamente para formar sua impressão. Ao contrário, tende a aceitar a imagem integral, como uma entrega já encaixotada. Em contraste, o espectador do mosaico da TV, com o controle técnico da imagem, inconscientemente reconfigura os pontos numa obra de arte abstrata, que se aproxima das esculturas de Seurat ou Roualt. (MCLUHAN, 1964, p. 352)
}

A televisão, assim, não forneceria a imagem detalhada dos objetos, deixando para o telespectador a função de unir os pontos para, então, transmitir a mensagem. Durante uma entrevista, perguntaram a Joanne Woodward qual é a diferença que sentia entre ser uma estrela de cinema e uma atriz de TV. Ela respondeu: "Quando eu trabalhava no cinema, ouvia as pessoas dizendo: 'Lá vai Joanne Woodward.' Agora elas dizem: 'Acho que conheço aquela moça' (MCLUHAN, 1964, p. 357).

Para o autor, um meio frio, como a televisão, daria mais margem ao receptor do que um meio quente como o rádio. Um meio quente, de alta definição, proporcionaria pouca participação. A televisão, portanto, de baixa definição, asseguraria um alto envolvimento da audiência, exigindo respostas criativas e participantes. Assim, "os programas mais eficazes seriam aqueles cujas situações consistem em processos que devem ser completados" (MCLUHAN, 1964, p. 359). 
Podemos considerar, então, que a televisão característica pela imagem mosaico, de baixa definição, já surgia com a proposta de meio frio e instigava o público ao envolvimento, ainda que a participação fosse bastante limitada. No entanto, a produção do conteúdo transmitido pela televisão estava centrada no emissor, sendo, desse modo, uma produção unilateral, não cabendo ao receptor uma participação efetiva no que diz respeito à produção da mensagem, ou mesmo ao feedback.

Portanto, o feedback dos telespectadores seria apenas a possibilidade de escolha entre os canais disponíveis, ou até mesmo entre outras atividades paralelas que substituiriam a televisão, e a interpretação da mensagem recebida. Os possíveis comentários e reações sobre o assistido seriam também uma forma de expressar sua opinião diante do comunicado.

Após o surgimento da internet, um veículo aberto e que garante ampla interatividade com o usuário, a possibilidade de interagir e participar da produção da mensagem tornou-se uma tendência. As novas gerações passaram a não aceitar tão facilmente a mensagem pronta, sem interação, com a mesma passividade que as antigas gerações. Assim, a ânsia por participar do processo como sujeito agente fez do recurso da interatividade a principal tendência no que diz respeito à comunicação mediada. O modelo emissor-receptor, linear e hierárquico, perderia espaço e seria facilmente substituído pela nova mídia que despontava atraindo cada vez mais usuários.

\section{A busca pela interatividade pós-internet}

Poderíamos afirmar que a internet foi um marco no que diz respeito à interatividade entre público e mídia. Os outros veículos de comunicação, como a televisão, buscariam, a partir daí, maior interatividade com seu espectador mesmo que os recursos tecnológicos limitados de sua plataforma não permitissem uma interação efetiva. Programas televisivos como Você Decide, exibido pela Rede Globo entre 1992 e 2000 intitulavam-se interativos 
e contavam com a opinião do público. A cada episódio de Você Decide, eram encenadas histórias que teriam seus finais escolhidos pelo telespectador através de votações via telefone.

O que se questiona, entretanto, é o poder de escolha limitado do público em programas televisivos como o acima citado, e se essa escolha se caracterizaria como interatividade. Em tais programas, o telespectador pode votar qual opção Ihe parece mais agradável ou mais adequada, porém, ele não cria propriamente nada, já que as opções disponíveis foram previamente produzidas e editadas pelas equipes de produção e edição do programa televisivo em questão.

Desse modo, para alguns autores, esse tipo de intervenção proposta se caracterizaria como reatividade (MACHADO, 1990). Segundo o conceito de reatividade, o receptor, no caso telespectador, apenas reage às incitações a partir das opções que Ihes estão disponíveis. No caso do programa Você Decide, o qual o próprio nome já faz com que o público pense que é ele quem realmente escolhe o que acontecerá no final da história, as opções foram criadas pela produção do programa e ao telespectador só lhe cabe as opções: um; dois ou três. Raymond Williams (1990, p.139), considerava a interatividade como "possibilidade de resposta autônoma, criativa e não prevista da audiência, ou mesmo, no limite, a substituição total dos pólos emissor e receptor pela idéia mais estimulante dos agentes intercomunicadores." Entendemos, então, que o leque limitado de possibilidades que os programas televisivos disponibilizavam para o público não garantiria a interatividade, apenas estimularia uma reação do mesmo ao escolher entre as opções disponibilizadas pelo emissor. O termo agentes intercomunicadores, proposto pelo autor, substituiria o emissor e receptor em uma comunicação totalmente interativa, já que os envolvidos no processo comunicacional passariam a ser agentes ativos e não mais polarizados. A possibilidade de um diálogo real garantiria a relação entre esses agentes quando se estabelece a comunicação. Nesse momento, portanto, a televisão não estava aberta às influências efetivas do telespectador em relação ao conteúdo e à forma de seus programas, e sua participação limitada sempre levava à escolha de opções pré-determinadas pelo emissor. 


\subsection{Níveis de interatividade}

O desenvolvimento tecnológico da televisão ao longo dos anos, desde o surgimento do primeiro modelo do aparelho, não apenas melhorou gradativamente a qualidade da imagem e som, mas alterou a relação entre mídia e telespectador no processo comunicacional. Ainda que o conceito de interatividade não esteja em conformidade entre alguns autores, os estágios dessa interação entre emissor e receptor através da mídia televisiva demonstram tais modificações. André Lemos (1997), por exemplo, define os diferentes níveis de interatividade proporcionados pela televisão. Para ele, quando surgiu o primeiro modelo em preto e branco, com um ou dois canais disponíveis, o nível de interação seria zero. Nele, o telespectador se limitava em ligar e desligar o televisor, escolher entre o canal um ou dois (no caso de dois canais), aumentar ou diminuir o volume e, no máximo, alterar o brilho e o contraste da imagem transmitida. Assim, a televisão era compreendida como um veículo de comunicação de mão única, com um fluxo linear da mensagem.

Em um segundo estágio, considerado por Lemos como nível um, a televisão aparecia em cores, em 1973, e, devido a sua expansão, outras emissoras despontavam garantindo ao público uma maior gama de possibilidades de escolha. O controle remoto passou a fazer parte integrante do televisor e o telespectador se sentia mais livre para "navegar", ainda que de forma limitada, entre os canais de TV. O controle remoto, em 1980, iria representar uma maior liberdade de escolha por permitir que o espectador, desde sua poltrona, passasse de um canal para o outro rapidamente quando um programa já não mais the interessasse. Esse modo de interface ficou conhecido como zapping ${ }^{3}$.

Seguindo a classificação dos níveis de interação, no nível dois, alguns apetrechos se acoplaram ao aparelho de televisão permitindo ao usuário a oportunidade de utilização do televisor para outros fins. O vídeo game, conectado ao televisor, possibilitaria maior entretenimento e interatividade, já que o usuário comandava o jogo e determinava o final de acordo com suas 
habilidades ao jogá-lo. O vídeo cassete também revolucionaria o ato de assistir televisão. Além de garantir autonomia, já que o telespectador poderia escolher o filme e o momento de assisti-lo, assim como no cinema, ainda proporcionava o conforto e os momentos de prazer que eram considerados os principais atrativos da "telinha". A temporalidade dos programas televisivos seria outro paradigma rompido com o surgimento do vídeo cassete, já que independentemente do fluxo temporal dos programas apresentados pela televisão, o telespectador agora tinha a possibilidade de gravá-los e assisti-los no momento em que lhe parecesse mais apropriado.

No nível três de Lemos, outros aparelhos se unem à televisão como sinais de interatividade. Nesse momento, o público já podia interferir de alguma forma na programação exibida pela televisão. Através do telefone, determinados programas convidavam o telespectador a dar opinião ou escolher a seqüência de programas ou episódios transmitidos. O fax e, posteriormente, o e-mail seriam outras formas de garantir a mesma interação.

A partir do nível quatro, descrito por Lemos (1997), o público deixaria de ser apenas receptor da mensagem televisiva já que a televisão passaria a ser interativa. A evolução tecnológica seria a grande determinante do processo de transformação da televisão, que chegaria, nesse momento, à digitalização. Aqui, o telespectador poderia escolher, inclusive, o ângulo da câmera que mais lhe agradasse e receber, assim, uma transmissão mais individualizada. No entanto, o receptor ainda pode ser denominado dessa forma porque não assumiu o controle sobre a programação. Ele ainda responde aos estímulos do emissor e caminha por estradas pré-determinadas. Seu leque de possibilidades é, sem dúvida, muito mais amplo, mas, no entanto, ainda é limitado.

Chegamos ao nível cinco, proposto por Lemos. Deparamo-nos com um cenário de maior liberdade, onde o telespectador passa a ter uma presença real no conteúdo transmitido pela mídia televisiva e não apenas escolhe entre as opções determinadas pelo emissor. Assim, ele participa da programação 
enviando vídeos, ainda que de baixa qualidade, à emissora. A produção de tais vídeos se dá através de webcams ou filmadoras, e o canal entre as duas pontas é garantido através da plataforma da internet. A internet, portanto, passou a ser um aliado da televisão na tentativa de proporcionar interatividade. Em níveis anteriores, a internet já era um meio de convidar o telespectador a interagir, ou reagir às incitações através de críticas e sugestões ao conteúdo apresentado, e, mais adiante, a realizar conversas virtuais mediadas com algum especialista ou celebridade.

O nível seis poderia ser considerado uma extensão do anterior, já que a proposta de interação é muito semelhante. A diferença estaria, então, na qualidade dos vídeos enviados pelo telespectador, que se assemelharia à da emissora.

É no nível sete que, para Lemos, a interatividade se dá efetivamente. Os conceitos de emissor e receptor já não podem ser aplicados, já que um passa a se confundir com o outro. Considerando essa classificação, o alto nível de interatividade se qualificaria por uma ampla disponibilidade de escolhas. 0 veículo de comunicação estaria, assim, aberto a receber influências externas, o que modificaria significantemente o resultado final do conteúdo apresentado por ele. Aqui, a televisão se pareceria muito à internet, já que qualquer pessoa que possuísse os equipamentos adequados poderia gerar conteúdo e enviálo para a emissora que o transmitiria. O diferencial entre ambos, porém, é que a liberdade na internet seria quase que total e irrestrita, enquanto que a televisão, assim como qualquer mídia de massa, a interação não é amistosa, já que existem interesses múltiplos como econômicos, culturais, políticos e assim por diante, que estão por trás da aparente capa da liberdade total.

\section{Nós: os co-produtores da informação}

Há algumas décadas pareceria improvável imaginar como seria possível romper a hierarquia na qual a comunicação midiática se estabelecia. Jornalistas, 
produtores e editores eram os responsáveis pela produção e edição da informação que nós, público, recebíamos, já que as barreiras que existiam entre o fato e o informado pareciam intransponíveis. A popularização do telefone garantiria uma comunicação "um para um". Os meios impressos e eletrônicos existentes até então (já incluindo aqui a televisão) propunham o "um para muitos", em que apenas um emissor transmitia a mensagem para vários receptores. A comunicação midiática unilateral estaria, no entanto, com seus dias contados, devido ao desenvolvimento tecnológico. Essa comunicação sofreria uma transformação sem precedentes a todos que tivessem acesso a um computador conectado à internet. Graças à nova mídia, nós poderíamos "ler" a mensagem de uma forma jamais vista antes, e o mais impressionante, nós poderíamos "escrevê-la", ou seja, produzi-la. Aquilo que os detentores da informação costumavam chamar de público já não poderia ser visto com os mesmos olhos e as relações entre emissor e receptor se alterariam consideravelmente.

Estamos, então, vivenciando a explosão de uma era em que a comunicação é digital e multidirecional. Nela, o público pode ser parte integrante do processo comunicacional, e o que se nota é a ânsia desse público em participar.

Inviting the audience to contribute isn't a new phenomenon. After all, we've asked readers to write letters to the editor for a long time, and we generally answer the phones when readers call with tips or complaints. In other words, some conversation has always taken place; we just need to have more (GILLMOR, 2004, p. 35).4

Essa pequena participação por parte do público descrita por Gillmor era, assim, a única forma de reagir à mensagem transmitida pela mídia antes do advento da internet. Hoje, vislumbramos um cenário bastante distinto. $\mathrm{O}$ público dessa nova era deixará, mais e mais, de ser apenas consumidor, para se transformar em usuário produtor de informação. Desse modo, percebemos que a democratização da comunicação garante ao público o poder de ser agente e informar uma platéia global. Alguns dos vídeos e fotos de maior impacto na internet foram produzidos por "amadores". As pessoas carregam por todas as 
partes celulares com câmeras cada vez mais avançadas tecnologicamente e prontas para registrar a qualquer momento qualquer imagem. Tais celulares estariam, ainda, conectados à internet, e, portanto, capacitados a enviar as imagens registradas instantaneamente à rede. Claro que os equipamentos usados por fotógrafos e cameramen são de qualidade muito superior a dos celulares, mas muitas vezes, o registro da imagem em si tem grande valor independente da qualidade técnica. Durante a guerra do Iraque, vários vídeos de tortura gravados pelo celular chegaram à imprensa por vias desconhecidas e foram vistos de forma negativa pelos próprios americanos. Sem dúvida, tais vídeos podem ter colaborado para a desaprovação da guerra por parte do povo americano e para o declínio da popularidade do ex-presidente George Bush. Seguramente, em outros tempos de guerra, certas atrocidades cometidas ficaram encobertas.

Nos últimos anos, nenhum evento teve tanta visibilidade quanto os ataques terroristas de 11 de setembro às torres gêmeas. Certamente, as imagens desse acontecimento, mostradas, praticamente, por todas as emissoras de televisão do mundo, ficarão eternamente registradas na memória de quem estava diante da TV. No entanto, outras imagens amadoras, que registraram o desespero de indivíduos que lutavam pela vida e para salvar tantas outras, apareceram na internet e muitas delas foram transmitidas via televisão.

A interatividade midiática, no entanto, principalmente no que diz respeito à televisão, continua sendo um fenômeno da comunicação em que ainda não há liberdade total de ambos os pólos da interação. A mídia, com seus editores, continua colocando no ar apenas o que for do seu interesse. Ela recorta o fluxo dos acontecimentos, selecionando imagens e discursos, oprimida tanto política como economicamente por algum interesse que está subjacente ao que se mostra na superfície. Assim, podemos partir da premissa de que a televisão, em si, não é um meio de comunicação interativo. Atualmente, é mais evidente a tentativa de inserir o telespectador no processo, através, principalmente, de vídeos caseiros, e contando, sempre, com a plataforma 
da internet. Todavia, a maior parte da programação televisiva não permite a participação do público, ela é pautada, produzida e editada exclusivamente por profissionais da emissora de TV.

\subsection{Current TV: em busca de novos paradigmas}

Entendemos que a internet, como nova mídia foi a protagonista de transformações no que diz respeito à interatividade e que a sua plataforma não apenas entrou no cenário comunicacional como garantia de democratização do conteúdo informado, mas também como colaboradora de outros meios, como a televisão, ao proporcionar a convergência midiática. No entanto, vimos que a maior parte da programação veiculada pela televisão não é comprometida com a interatividade, e, na maioria dos casos, quando há algum nível de interatividade, não se trata da interação mútua, mas sim da reativa.

[...] a interação mútua é aquela caracterizada por relações interdependentes e processos de negociação, em que cada interagente participa da construção inventiva e cooperada do relacionamento, afetando-se mutuamente; já a interação reativa é limitada por relações determinísticas de estímulo e resposta (PRIMO, 2007, p. 57).

Assim, uma produção colaborativa se configuraria na interatividade mútua, na qual o usuário/espectador teria a possibilidade de criação ou reelaboração do conteúdo a ser transmitido via televisão. Percebemos, no entanto, que a internet também entrou no cenário comunicacional como ditadora de tendências, demandando, cada vez mais, das duas partes interessadas. À primeira, conceitualmente denominada emissor, cabe a busca por mais meios que possibilitem melhor interação e participação do espectador. À segunda, conceitualmente denominada receptor, utilizar desses meios para incluir-se significantemente na conversa mediada, e por que não, produzir a mensagem.

Ainda que o modelo de fazer televisão tenha sido pouco alterado, como vimos anteriormente, algumas emissoras de televisão estão inovando 
e permitindo a colaboração do espectador/usuário na produção de conteúdo televisivo. Este é o caso da TV americana Current $T V^{5}$, focada na interação mútua, na qual cerca de $25 \%$ da programação exibida é criada pelo público, e a tendência, segundo a própria emissora, é que esse número seja cada vez maior.

Sem a convergência entre internet e televisão seria impossível a realização do projeto proposto pela emissora, que, além de seu próprio site, está online através dos sites e redes sociais Facebook, Twitter, YouTube, iTunes e Hulu e é transmitida via cabo e satélite pelos canais 358 (DirectTV); 196 (Dish Network); 107 ou 125 (Comcast); 103 ou 142 (Time Warner Cable); 189 (AT\&TU-Verse) e 192 (Verizon FIOS), chegando às mais de vinte milhões de residências americanas que possuem acesso à TV a cabo ou via satélite. Sua programação é composta por notícias; documentários; esporte e aventura e programas de entretenimento como qualquer outro canal de TV. O que diferencia a Current TV da maioria das outras emissoras é a maneira com que o telespectador, também um usuário, é convidado a participar do processo de produção e até de edição da mensagem transmitida.

Em parte da programação, a participação não pode ser considerada totalmente interação mútua, como é o caso de The Rotten Tomato, um programa baseado em críticas de filmes que conta com a participação dos internautas para a classificação dos filmes via internet, que, posteriormente, é divulgada no programa televisivo. No entanto, além da classificação geral, o programa seleciona os melhores comentários feitos pelos internautas a respeito dos filmes e os transmite via TV.

Mantendo a proposta de interatividade, a Current TV possui um link em seu website exclusivamente dedicado à participação dos usuários/espectadores: o "Participate". Nele, os usuários podem participar do Big Featured Discussions, local onde os produtores da emissora colocam os assuntos de maior destaque que serão, posteriormente, apresentados na televisão para serem discutidos pelos internautas. Estas discussões e sugestões de pauta são utilizadas 
pelos produtores para aprimorar o conteúdo dos programas, a maioria deles documentários. Um exemplo de como o ele funciona é o documentário apresentado pela TV em questão na primeira semana de julho sobre extremistas islâmicos. Para a produção do mesmo, a TV postou um vídeo em seu site no formato de documentário com a seguinte temática: Should the U.S. treat "homegrown" Islamic extremists differently from those who are not citizens?6. Foram quarenta e dois comentários, e, entre eles, um suposto melhor amigo de extremista islâmico. A partir daí, a produção reformulou o documentário, incluindo a história do internauta, para a exibição via cabo e satélite.

Ainda no link "Participate", o internauta pode interagir no Post a Story, um local dedicado à postagem de links, vídeos e histórias originais. Assim que a produção da emissora recebe as sugestões ou produções dos usuários, ela faz uma pré-seleção e coloca no site os vídeos e história mais interessantes, de acordo com o ponto de vista da emissora. Na seqüência, o usuário participa do processo de edição, já que ele irá elencar, entre os tantos vídeos e histórias, aqueles que mereceriam ir ao ar via televisão.

Percebemos, aqui, a real tentativa de inserir o usuário/espectador no processo de produção e edição do noticiado, ainda que se note a característica presente em qualquer emissora de televisão convencional ao fazer uma pré-seleção e excluir conteúdo que não seja de seu interesse ou que não dialogue com o seu perfil. De qualquer modo, podemos afirmar que a Current TV busca inovar quando abre um espaço real, de quase um quarto de tudo o que é produzido, para a participação do receptor, garantindo a interação mútua, que, segundo Alex Primo (2007), se daria através da construção inventiva de ambas as partes.

Buscamos, ainda, entender como está estruturado o setor comercial da emissora ora em questão. Como qualquer outra emissora privada, a Current TV mantém-se por meio de publicidades apresentadas tanto em seu formato online quanto via satélite e cabo. Todavia, além das publicidades tradicionais 
produzidas por agências publicitárias, a emissora abre um espaço aos usuários denominado VCAM - View Created Ad Massage, o qual permite e convida o público a criar anúncios publicitários para os patrocinadores da emissora. Em seu link na internet, o VCAM anuncia: Get creative; Get on TV; Get Paid. Assim, os usuários que produzirem um anúncio publicitário escolhido pelo anunciante receberão entre $\$ 2.500$ e $\$ 60.000$ por ele. Como exemplo, a marca Sun Chips optou por cinco vídeos publicitários produzidos por internautas e postados no site da Current TV, todos eles foram veiculados via televisão, juntamente com o nome e foto de seus produtores.

Observamos, então, que o público atua em todos os processos da produção do conteúdo, já que, aparentemente, até mesmo a seleção final de parte da programação que vai ao ar é feita por ele, o que normalmente cabe à emissora de televisão. Aparentemente porque a decisão e as conseqüências do que é veiculado é de responsabilidade quase que total da emissora. O conceito grassroot journalism, de Dan Gillmor (2004), se aplica à forma de produção e veiculação do conteúdo apresentado pela televisão americana Current TV, já que o noticiado também é produzido pelas pessoas e para as pessoas.

The Internet is the most important medium since the printing press. It subsumes all that has come before and is, in the most fundamental way, transformative. When anyone can be a writer, in the largest sense and for a global audience, many of us will be. The Net is overturning so many of the things we've assumed about media and business models that we can scarcely keep up with the changes; it's difficult to maintain perspective amid the shift from a top-down hierarchy to something vastly more democratic and, yes, messy. But we have to try and making our own news nowhere is that more essential than in that oldest form of information: the news (GILLMOR, 2004, p. 237). ${ }^{7}$

A internet, então, abriria as portas para as mudanças de paradigmas da comunicação top down, em que a mensagem era produzida exclusivamente pelo emissor (top) e transmitida para o receptor (down). No caso da Current $T V$, a criação e disseminação da mensagem se dão democraticamente, de forma que qualquer usuário pode participar. Por isso, ela já é comparada à internet e denominada por seus próprios usuários de Blog TV. 
Quando a internet popularizou-se, na década de 90, nós não tínhamos idéia de como ela influenciaria nossas vidas. Mais do que isso, nós não poderíamos prever o poder que ela nos proporcionaria. Dessa forma, a comunicação mediada por computadores está se irradiando pelo mundo, ainda que a inclusão digital esteja longe de se estabelecer em muitos países em desenvolvimento. A parte do planeta que já está conectada interage entre si, reforçando a dimensão de globo. As sociedades estariam, desse modo, organizadas em torno de redes, as quais modificam substancialmente a morfologia do nosso meio (Castells, 2001). Essas redes comunicacionais seriam estruturas flexíveis, com capacidade de expansão ilimitada e de tempo indeterminado, quase que infinito. Assim, quando Gillmor fala da captura das idéias que cada um de nós tem a oferecer, ele inclui todas as formas de comunicação que podemos compartilhar na rede, e mais além, através da convergência midiática, enviar conteúdo para que a televisão o transmita. We the Media (Nós a mídia), título de seu livro, seria a melhor definição para o fenômeno que acabamos de descrever, no qual a democratização da comunicação se faz presente. 


\section{Referências}

BUCCI, Eugênio; KEHL, Rita Maria. Videologias: ensaios sobre a televisão. São Paulo: Boitempo, 2004.

CASTELLS, Manuel. La Galaxia Internet. Barcelona: Plaza\&Janes, 2001.

CASTELLS, Manuel. A Sociedade em Rede. São Paulo: Paz e Terra, 2001.

DEBORD, Guy. A Sociedade do Espetáculo. Rio de Janeiro: Contraponto, 1997.

GILLMOR, Dan. We The Media: grassroots journalism by people, for the people. Disponível em http://www.oreilly.com/catalog/wemedia/book/index.csp - consultado em: 23 de dezembro de 2008.

JENSEN, Rolf. The Dream Society: How The Coming Shift From Information to Imagination Will Transform Your Business. New York: McGraw-Hill, 1999.

KERCKHOVE, Derrick. O negócio da interactividade. In Inteligência Conectiva. Traduzido por Ana Viseu e publicado em 1998. Disponível em http://fcis.oise.utoronto.ca/ aviseu/ portu_currículo_content.html - consultado em: 20 de setembro de 2008.

LEMOS, André. Anjos interativos e retribalização do mundo: sobre interatividade e interfaces digitais. 1997.

Disponível em www.facom.ufba.br/pesq/cyber/lemos/interac.html - consultado em 20 de dezembro de 2008.

MACHADO, Arlindo. A Arte do Vídeo. São Paulo: Brasiliense, 1990.

MCLUHAN, Marshall. Os Meios de Comunicação como Extensões do Homem. São Paulo: Cultrix, 1964.

NEGROPONTE, Nicholas. A vida Digital. São Paulo: Companhia das Letras, 1996.

PRIMO, Alex. Interação Mediada por Computador. Porto Alegre: Sulina, 2007.

SILVA, Marco. Interatividade: Uma Mudança Fundamental do Esquema Clássico da Comunicação. 2000. Disponível em HTTP://www.senac.br/informativo/bts/263/ boltec263.htm - consultado em 20 de dezembro de 2008.

WILLIAMS, Raymond. Television: Technology and Cultural form. Londres: Routledge, 1990. 
1 Trabalho apresentado no GP Televisão e Vídeo, X Encontro dos Grupos de Pesquisas em Comunicação, evento componente do XXXIII Congresso Brasileiro de Ciências da Comunicação.

2 Doutoranda em Comunicação pela Universidade Metodista de São Paulo (UMESP), mestre em Comunicação Midiática pela Universidade Estadual Paulista - UNESP (2009). Possui graduação em Comunicação Social com habilitação em Jornalismo pela Universidade Metodista de São Paulo (2000). Atualmente é bolsista CAPES. Tem experiência na área de Comunicação, com ênfase em Comunicação Midiática, atuando principalmente nos seguintes temas: mídia, espetáculo e pós-modernidade.

3 A palavra zapping tem a sua origem no inglês zap, e consiste em mudar de canal de televisão constantemente, fazendo uso do tão clássico controle-remoto.

4 "Convidar o público para contribuir não é um fenômeno novo. No final das contas, nós pedimos aos leitores para que escrevam cartas ao editor há muito tempo, e nós geralmente atendemos ao telefone quando leitores ligam dando sugestões ou fazendo reclamações. Em outras palavras, algumas conversas sempre aconteceram; nós apenas precisamos de mais." (tradução nossa)

5 Current TV é uma televisão americana a cabo, via satélite e via internet. Segundo informações de seu site, "Current is about what's going on in your world: all the things you and your friends are actually interested in -- that you won't find on any other news site or cable TV channel. Current.com is the place to find and share stories and videos that are interesting to you. It connects to Current TV, a global cable and satellite TV network. Current (nome da TV que quando adjetivo significa atual ou circulante) é sobre o que está acontecendo no seu mundo: todas as coisas que você e seus amigos estão realmente interessados - que você não encontrará em nenhum outro site de notícias ou canal de TV a cabo. Current.com é o lugar para encontrar e dividir histórias e vídeos que são interessantes para você. Ele se conecta com Current TV, uma televisão global a cabo e via satélite. (tradução nossa)

6 "Os Estados Unidos deveriam tratar islâmicos extremistas que cresceram no país de forma diferente daqueles que não são cidadãos americanos?" (Tradução nossa)

7 A internet é o mais importante meio desde a imprensa escrita. Ela inclui tudo o que veio antes e é, da forma mais fundamental, transformadora. Quando qualquer um pode ser um escritor, no sentido mais amplo e para uma platéia global, muitos de nós seremos. A rede está fragmentando muitas das coisas que nós assumimos como mídia e modelos de negócios e nós dificilmente conseguimos nos manter atualizados com as mudanças; é difícil manter uma perspectiva em relação ao deslocamento da hierarquia top down para alguma coisa vastamente mais democrática e, sim, bagunçada. Mas nós temos que tentar e fazer nossas próprias notícias já que nenhum lugar é mais essencial do que a forma mais antiga de informação: a notícia. (tradução nossa) 